\title{
A LEI DE ARBITRAGEM NA ADMINISTRAÇÃO PÚBLICA
}

\section{Márcio Bonini Notari}

Graduado em Direito pela Universidade Católica de Pelotas/ RS - Ucpel. Especialista em Direito e Processo do Trabalho pela Faculdade Atlântico Sul, Pelotas/RS. Especialização em Filosofia pela Universidade Federal de Pelotas/RS. Mestre em Direitos Sociais e Políticas Públicas pela Universidade de Santa Cruz do Sul, Unisc/RS. Professor do Colegiado de Direito da Faculdade Unesc/ Rondônia. marciobnotari@gmail.com

\section{Resumo}

0 presente artigo tem por objetivo analisar o projeto de Lei, em tramitação no Senado Federal, que altera alguns dispositivos da Lei 9.307/96, instituindo a possibilidade de aplicação da Lei de Arbitragem no âmbito da Administração Pública. No primeiro momento será abordado 0 conflito a partir da teoria marxista e sua concepção acerca do Estado e do direito, enquanto aparelhos ideológicos, repressivos e intermediários dos interesses das classes dominantes, reproduzindo a lógica do sistema capitalista de produção no uso da violência simbólica para a resolução das celeumas sociais. No segundo instante 0 trabalho irá tratar alguns fatores atinentes à crise do poder jurídico estatal na solução das demandas presentes no tecido social, verificando, em especial, alguns fatores decorrentes da cultura normativista predominante na formação do jurista e suas implicações quanto à forma litigiosa no tratamento das lides. No terceiro ponto será abordado o novo projeto de Lei, em tramitação junto ao Senado Federal, que institui a aplicação do instituto da arbitragem, em se tratando de conflitos envolvendo a administração pública.

\section{Palavras-chave}

Estado. Direito. Capitalismo. Conflitos. Arbitragem e administração pública.

\section{ARBITRATION LAW ON PUBLIC ADMINISTRATION}

\section{Abstract}

His article aims to analyze the draft law, in progress in the Senate amending some provisions of Law 9.307/96, establishing the possibility of applying the Arbitration Law in Public Administration. At first, the conflict will be addressed, from the Marxist theory and his conception of the state and law, while ideological, repressive and intermediate the interests of the ruling class devices, reproducing the logic of the capitalist system of production, the use of violence symbolic for the resolution of social uproar. In the second moment, the work will address some factors relating to crisis of state legal power to solve the demands present in the social fabric, checking in particular some factors arising from normative culture predominant in 
the formation of the jurist and its implications for the way in litigation treatment of chores. On the third point, will address the new draft law, in proceedings before the Federal Senate, establishing the application of the concept of arbitration, in the case of conflicts involving public administration.

\section{Keywords}

State. Right. Capitalism. Conflicts. Arbitration and public administration.

\section{Sumário}

1 Considerações Iniciais. 20 Conflito Enquanto Fenômeno Global e Local: Apontamentos Marxistas. 3 A Crise do Poder Jurídico Estatal no Tratamento de Conflitos. 4 A Lei da Arbitragem no Âmbito da Administração Pública. 


\section{CONSIDERAÇÕES INICIAIS}

A autocomposição para lidar com os conflitos que desaguam no Poder Judiciário é, atualmente, um dos temas mais debatidos e analisados por estudiosos do Direito e de áreas afins. Trata-se de procurar, a partir de soluções alternativas, uma mudança paradigmática aos problemas que surgem das relaçôes humanas e sociais, que não esteja interligada somente à cultura da litigância, autor/réu, reclamante/reclamado, querelante/querelado, reconvinte/reconvindo, demandante/demandado, executante/executado, em que ocorre a expansão de atribuiçóes jurisdicionais ao Judiciário, no que respeita aos procedimentos e ao processo, o qual acaba sendo dispendioso, lento e burocrático, exigindo a instituição de novos mecanismos eficazes, desburocratizados e informais, isto é, uma nova cultura no tratamento dos conflitos.

A questão central que se coloca para o presente trabalho é a instituição do mecanismo da Lei de Arbitragem no âmbito da administração pública em tramitação no Senado Federal, e a maneira pela qual será enfrentado o problema referente a sua aplicabilidade quando houver o confronto com princípios constitucionais da legalidade, impessoalidade, publicidade e o interesse público/ coletivo a ser protegido diante da característica arbitral de natureza privada, negocial e contratual.

O objetivo será demonstrar os riscos inerentes dessa nova forma de resoluçáo de conflitos em uma perspectiva marxista, quando estáo em jogo os interesses privados dos setores dominantes, podendo o Direto e o Estado serem utilizados como intermediários para instrumentalizar mecanismos institucionais que desvirtuam os mecanismos de autocomposiçáo para fins eminentemente econômicos, deixando em caráter periférico o diálogo entre as partes e a expectativa dos vulnerabilizados econômica e socialmente.

Considerando que nosso trabalho é de natureza bibliográfica, o método de abordagem adotado no seu desenvolvimento será o dedutivo, tendo como pressuposto argumentos gerais e para argumentos particulares; quanto ao procedimento será o dialético, tendo como pressuposto a tese e uma antítese para daí se extrair uma síntese. 


\section{CONFLITO ENQUANTO FENÔMENO GLOBAL E LOCAL: Apontamentos Marxistas}

A crise existente no Estado contemporâneo (o c indica que se está falando do Estado nos dias atuais e não apenas enquanto Estado Contemporâneo caracterizado por seu poder finalístico, vinculado a sua função social), indica a necessidade de rever todos os seus papéis, tanto na esfera econômica quanto nos modelos de regulação social e jurídica tradicionais (Spengler, 2010, p. 36).

Um dos aspectos da referida crise está relacionado à supremacia absoluta da lei no Direito legislado como único critério de valoraçáo do comportamento social do homem. A crise decorre da desregulação estatal, da lentidão em dar respostas a demandas cada vez mais rápidas, da incapacidade de ocupar o seu espaço, dando margem ao surgimento do Direito inoficial e do Direito marginal, enfim, ao descolamento entre a legislaçáo posta e a realidade social (Spengler, 2010, p. 39).

Verifica-se a retração do Estado, que possui como função a proteção dos direitos dos cidadáos, e, diante da sua ausência ou ineficiência do Estado, o cidadão, muitas vezes, cria ou diz o Direito. Dessa forma, a função de dizer o Direito, que era monopólio do Estado, passa a ser realizada pela esfera privada, caracterizando um dos aspectos de sua crise, vista como uma interferência de um dos três poderes sobre as atribuiçóes do outro ou interferência supraestatal em sua soberania.

Essa crise acaba requerendo a transformação do Estado Contemporâneo, o que ocasiona um paradoxo a partir de um Estado mínimo ou um poder estatal interventor; o acompanhando em sua história até os dias atuais, quando uma das principais características é a multiplicação dos locais de poder, em uma superação da supremacia da ordem estatal, seja por organizaçóes supraestatais, seja pela ordem econômica, que passa por uma crise funcional em consequência da perda de centralidade e exclusividade do Estado em suas funçôes (Spengler, 2010, p. 45-46).

Disso decorre o que Spengler (2010, p. 46) denomina de possibilidade de concorrência entre o poder estatal e outros setores semipúblicos, privados, marginais, internacionais, supranacionais, que interferem na capacidade e na legitimidade de decidir sobre a lei e o tratamento dos conflitos sociais. Assim, ocorre a descentrali- 
zação do poder, cuja principal consequência é a minimização da capacidade estatal de cumprir suas funçôes refletidas na perda de sua legitimidade e na debilitação de sua própria existência. Logo,

Na medida em que não é possível trabalhar com a ideia de morte do Estado, exsurge a possibilidade de sua adaptação/transformação, repensando os papéis no âmbito nacional ou internacional, eis que passa por uma desregulação cujo principal ponto é a globalização em todos os seus aspectos (econômico, cultural, político e social). A globalizaçáo econômica surgiu principalmente com a emergência de uma nova divisão da produçáo inaugurada pelas grandes corporações multinacionais que têm origem nos EUA, Japão e Europa Ocidental, as quais calcadas, objetivamente, em construir uma nova ordem economia mundial sem fronteiras, unindo comunicação e controle em tempo real, o que é permitido com as inovações tecnológicas (Spengler, 2010, p. 54).

Essa perspectiva acarreta em inovar, pois, ao oferecer restriçôes à regulação estatal da economia e ao defender a subordinação dos Estados nacionais às agências multilaterais, como Banco Mundial, FMI e Organização Mundial do Comércio, pode causar o desemprego estrutural permanente (empregabilidade), sendo consequência também da globalização o clima e a segurança (intimamente ligados a questôes de equilíbrio mundial).

Nesse sentido, essa possibilidade de crise global e a constatação de que somente o Estado e o mercado náo vão resolvê-las, tende a fortalecer o papel das ONGs enquanto organizaçóes da sociedade civil na construção de alternativas e de mecanismos de cooperação internacional. As ONGs, em razão de seu prestígio, podem ter, em alguns casos, maior poder que o próprio Estado. Logo, a globalizaçáo é um processo inevitável, de inclusáo forçada, uma vez que incluído em um sistema internacional (Spengler, 2010, p. 55-56).

A sua principal manifestação é o fim das fronteiras, traduzido pelas práticas transnacionais que destroem a capacidade do Estado de controlar e conduzir o fluxo de pessoas, bens, capitais ou ideias. A crise de legitimidade, causada pela globalização, interage com o surgimento de movimentos sociais que afirmam identidades alternativas, rejeitando a legitimidade estatal, existindo, assim, uma relação tripartite entre globalização, mercado e movimentos sociais. 
A nova desordem mundial e a desregulação do direito: a atividade estatal deslocada. Esse fator causa a impressão de desordem mundial deixada pela globalização, que gera uma produção normativa cuja proliferação anárquica traduz uma impressão quantitativa reconhecida como uma avalanche de normas. Assim, ao contrário do que se pensa, desregulamentação não é o inverso da regulamentação, mas, sim, o reemprego das normas segundo seus dispositivos mais opacos e complexos (Spengler, 2010, p. 59).

Outrossim, a necessidade de superar o consenso global do direito, voltado ao desenvolvimento econômico, acaba exigindo do direito uma função crucial na regulação das sociedades e na sua forma de contribuição para a construção de uma sociedade mais justa. Para tanto, a resposta mais frágil consistiria em reduzir esta discussão ao âmbito do consenso global, formado pelo Banco mundial, FMI e Agências multilaterais e nacionais acerca da importância do Estado de direito e das instituiçôes jurídicas para assegurar o desenvolvimento econômico. Vale as seguintes liçôes sobre esse aspecto:

Faz parte dessa história complicada também um aspecto mais cotidiano dentro da prática dos sistemas jurídicos; hoje, o direito é constantemente forçado a decidir seguindo a crescente urgência dos problemas e das suas conexóes (complexidade é também isso) e é por isso obrigado a ajustes dos ajustes anteriores: o êxito é aquele de uma provisoriedade de todas as normas adotadas. O problema se torna aquele de um direito intertemporal continuamente transitório que obriga a incerteza própria, bem como dos seus destinatários. Um exemplo que temos sob os olhos é aquele da programação dos currículos universitários, mas podemos voltar o olhar às regras do capital financeiro; em relação às questôes do corpo e da vida, vimos o problema da identidade intertemporal dos indivíduos que o direito reduz a custo de qualquer paradoxo regulativo (Resta, 2014, p. 33).

Conforme entendimento de Santos (2007, p. 20), "a resposta forte exige que se contradite este consenso hegemônico, indagando quais as condiçóes para a construção de um novo senso comum jurídico e o seu papel para a emancipação social. $\mathrm{O}$ autor identifica um dos grandes campos em relação à construção do judiciário: o campo hegemônico intenta uma reforma que melhor servem aos 
interesses econômicos, deixando os demais setores da sociedade civil em situação periférica. Tais reformas são orientadas, quase exclusivamente, pela ideia de rapidez, na busca de um sistema de justiça célere.

Numa perspectiva marxista, conforme ensina o francês Louis Althusser, o que distingue os Aparelhos Ideológicos do Estado dos Aparelhos (repressivos), seria o fato de que os primeiros funcionariam pela violência, enquanto os segundos funcionariam pela ideologia. Nesse sentido, o Direito pertenceria, simultaneamente, ao Aparelho (repressivo) de Estado e ao sistema dos Aparelhos Ideológicos do Estado, ao lado da escola, família, religião, imprensa e partidos políticos. Nesse ponto,

O Aparelho de Estado (AE) compreende: o Governo, a Administração, o Exército, a Polícia, os Tribunais, as Prisōes, etc., que constituem o Aparelho Repressivo de Estado. Essa ideia de repressão, nessa vertente, indicaria que o Aparelho de Estado em questáo funciona pela "violência", pelo menos no limite; ela pode funcionar de maneira direta, como no caso da polícia, mas também, poderá ser realizada de maneira indireta, como no caso da repressão administrativa, a qual embora funcione secundariamente pela ideologia (AE), poderá ser revestida de formas não físicas de violência (Althusser, 1985, p. 43-44).

Calcado no materialismo histórico de Marx, que tem como fundamento as relaçóes sociais, históricas, produtivas, etc., são concebidas as estruturas de qualquer sociedade, constituídas pelos níveis ou instâncias, articulados por uma determinação específica. Essa determinação terá como ponto de partida a infraestrutura ou base econômica, que o autor denomina de unidade das forças produtivas e das relaçóes de produção, e a superestrutura que comporta em si mesma duas instâncias: a jurídico-política, que inclui o Direito e o Estado, as diferentes ideologias (religiosas, moral, jurídica, política, etc.).

Sendo assim, tomando por base as liçôes do materialismo histórico de Marx, segundo Althusser (1985, p. 24-25), “a história tem em seu perfazimento não somente os indivíduos, mas sim na raiz econômica produtiva da sociedade, isto é, nas condiçóes materiais de vida”. Por conseguinte, na visão de Muller (2007, p. 18), "para que possa compreender o conflito a partir da concepção da não-violência, deve-se primeiro entender o significado da violência e dos conceitos de conflito, agressividade, luta, força, coerção e por fim da violência”. 
Primeiramente, o conflito faz-se presente em todo comportamento humano, com relação ao outro, aos objetos ou aos desejos, dentre muitas outras possibilidades. O conflito agrava-se nas diferenças e adversidades. Genuinamente, o ser humano cria o conflito como um mecanismo de defesa diante do que não conhece ou lhe é antipático. Os desejos de posse e poder sobre objetos acabam interligando-se. Ao mesmo tempo em que os indivíduos entram em rivalidade para se apropriar dos objetos, digladiam-se para afirmar seu poder. Existe, portanto, um elo orgânico entre propriedade e poder.

O que está em jogo nos conflitos que opóem os homens geralmente é o desafio do poder. Não resta dúvida de que cada indivíduo necessita ter objetos suficientes para satisfazer suas necessidades vitais - alimentação, moradia, vestimenta -, tanto quanto precisa do poder adequado para ter seus direitos respeitados. Se, porém, os desejos de posse e poder são legítimos, na medida em que permitem ao indivíduo tornar-se autônomo em relaçáo aos demais, ambos possuem uma tendência natural para exigir e se desenvolver sempre mais. [...] Em um primeiro momento, o indivíduo busca o poder para não ser dominado pelos outros, mas, se não estiver atento, extrapola rapidamente o limite a partir do qual busca dominar os outros (Muller, 2007, p. 19).

A partir dessa fuga do conflito, o indivíduo estará automaticamente renunciando seus direitos. Deverá, portanto, aceitá-lo, por meio do qual se fará reconhecido pelos demais indivíduos. Desse modo, o conflito demonstra uma dualidade, podendo ser destruidor e também construtivo. O conflito é um elemento estrutural porque estabelece uma espécie de contrato, em que os adversários pactuam interesses que satisfazem seus direitos. Caso seja bem-sucedido, essa espécie de contrato pode construir relaçóes de equidade e justiça entre os indivíduos, na mesma e entre diferentes comunidades.

Nesse ponto, obtempera Gabriela Maia Rebouças:

A complexidade e diversidade de arranjos sociais, com seus encontros e desencontros, a pluralidade de valores, a possibilidade de exercitar em graus diferentes a própria liberdade, gozando de oportunidades sempre contingentes, irão multiplicar em demasia as formas, objetos e maneiras de relaçóes, que podem assumir uma tensão conflituosa. Contudo, equiparar o conflito a uma disputa 
é também reduzir suas potencialidades. Uma das percepções fundamentais é a de que a disputa não é o conflito, mas uma decorrência do conflito, eis que resolver a disputa não pôe fim ao conflito subjacente, pois conflito, pressupóe, a ideia de dissenso (2012, p. 166-167).

Nesse contexto, ocorre que o controle sobre recursos, como propriedade, poder, bens de consumo, espaço, preferências e incômodos, implica: exposição da sensibilidade, das suscetibilidades, do próprio modo de agir cotidiano; valores ou conflitos sobre o que deveria ser, marcando os conflitos de natureza política, ética, ideológica, cada vez mais abundante em contextos de sociedades diversificadas, plurais e democráticas; e crenças, isto é, conflitos sobre as percepçóes da realidade, fatos, informaçôes e conhecimentos.

A dinamicidade dos conflitos também envolve um reconhecimento, mais ou menos geral, de que não há um meio de resolução que seja preferível aos demais, em absoluto. Diversidade de atores, de pessoas envolvidas, de interesses, bens, contextos sociais, instruçáo, personalidade, enfim, diversidade de subjetivação, requer um leque igualmente e diversificado de procedimentos e sistemas de resolução, com nuances, flexibilidade e adaptabilidade (Rebouças, 2012, p. 169).

Segundo Muller (2007, p. 20), “isso implica a criação de instituições, a elaboração de leis que forneçam modalidades práticas de resolução social dos conflitos que, em qualquer momento, podem ocorrer entre os indivíduos”. Logo, a não violência não é pressuposto para a ausência de violência, da mesma forma que a paz não é a ausência de conflitos; a paz é o controle dos conflitos, as adequadas gestão e resolução que repudiam as práticas destruidoras e mortais.

Sendo assim, as relaçóes humanas, em razão da sua complexidade e múltiplas faces, acabam experimentando, de certa forma, o conflito em determinados momentos, não sendo algo necessariamente ruim ou anormal, posto que ele é um fato presente no mundo da vida, o qual exsurge quando as pessoas estão envolvidas na competição para atingir objetivos incompatíveis. A ideia de conflito, portanto, não se resume ao comportamento litigioso, delineando a intenção de infligir dano físico ou psicológico ao oponente. Daí surge a necessidade de procedimentos judiciais 
ou extrajudiciais eficientes, de forma adequada para tratá-lo. No ponto seguinte, será objeto de análise a crise do Poder Judiciário em relação às formas criadas para tratamento de conflitos.

\section{A CRISE DO PODER JURÍDICO ESTATAL NO TRATAMENTO DE CONFLITOS}

A expressão política pública é definida como um programa ou quadro de açáo governamental, porque consiste em um conjunto de medidas articuladas na busca da concretização de direitos. A formulação de políticas públicas enquanto atividade de planejamento sempre leva em consideraçáo o objetivo que se pretende atingir, bem como a finalidade almejada. Em se tratando da busca de solução de conflitos sociais, as políticas públicas podem ocorrer paralelas ao Poder Judiciário ou, ainda, serem anteriores ao processo judicial (Morais; Spengler, p. 169).

A crise do Poder Judiciário no Brasil, explana teoricamente sobre os problemas que estão sendo enfrentados pela jurisdição de conflitos e acesso à justiça, o que impacta na democracia nacional, ocasionando problemas. Em razão dessa crise, diversas são as alternativas de resolução de conflitos que estão surgindo no âmbito nacional, muitas delas não estatais. Essa crise estatal traz consequências para a jurisdição estatal, sofrendo influências negativas da globalização como um todo.

O Estado vem perdendo soberania e fragilizando-se em todas as esferas, e o mercado, em contrapartida, vem ganhando poder e influenciando todas as esferas estatais. Destacam-se dois dos grandes problemas que influenciam na crise estatal, segundo Spengler (2014, p. 14): "sua incapacidade de dar respostas céleres aos litígios atuais; e sua perda de forma relativa na exclusividade de dizer e aplicar o direito".

Nesta seara, observa-se que os conflitos sociais que chegam ao Judiciário precisam deixar de ser analisados como meras abstraçóes jurídicas, olhando-se para os protagonistas dos processos judiciais como pessoas com rostos e histórias que requerem respostas qualitativas e rápidas para suas demandas. E nesse sentido que a harmonia precisa ser instalada, equilibrando respostas qualitativas em tempo razoável que possam ultrapassar o tripé (autor, réu e juiz) para instituir um processo dicotômico que trabalhe com os indivíduos, devolvendo-lhes a capacidade de tratar o conflito de maneira consensual para obtenção de uma resposta mais democrática. 
A justiça em números e as dificuldades da jurisdição brasileira em responder aos conflitos sociais, demonstram que o Poder Judiciário não consegue dar uma resposta adequada à sociedade no que diz respeito a prazos processuais para se buscar ao máximo uma possibilidade de se fazer justiça, em razão da burocratização do Sistema Judiciários Nacional. O modo de vida globalizado exige resoluçóes cada vez mais rápidas dos problemas decorrentes do dia a dia, o que esbarra na quantidade de demandas judiciais e no tempo do processo (Spengler, 2014, p. 17).

Os juizados especiais, por exemplo, têm sido apontados como uma das melhores soluçôes, dentro de uma estrutura do Judiciário, para dar celeridade à solução das lides e aproximar a decisão judicial dos cidadãos com base na oralidade, informalidade, conciliação, transação e desistência de recursos, extinguindo o reexame necessário. Conforme Santos (2007, p. 60), no ano de 2004 a taxa de congestionamento na Justiça Federal foi de $84 \%$ da Justiça Comum contra 52\% dos juizados especiais federais, quando cinco regiôes da Justiça Federal receberam mais de 1,7 milhão de processos.

Os indicadores relacionados ao judiciário nacional vem demonstrando a situaçáo dos últimos anos, em primeiro e segundo grau de jurisdição, da movimentaçáo processual brasileira, mediante a explanação sobre a quantidade de processos tramitando/baixados, a quantidade de novos processos, a taxa de congestionamento, a carga de trabalho por magistrado, a quantidades de processos julgados/pendentes na justiça federal, na justiça do trabalho e na justiça estadual, demonstrando a complexidade do problema a ser enfrentado no Poder Judiciário brasileiro que se encontra em crise tendo em vista a carga processual, a burocracia, a ineficiência e a ineficácia do sistema de justiça (Spengler, 2014, p. 17).

Esse cenário denota um pouco da incapacidade da Jurisdição de monopolizar a resolução dos conflitos. A tendência é a de se desenvolver procedimentos jurisdicionais complementares, como a arbitragem, a mediação, a conciliação e a negociação, almejando alcançar celeridade, informalização e pragmaticidade. Essa crise do Judiciário brasileiro pode ser entendida como uma crise de identidade, a qual se refere a um embaçamento do papel judicial como mediador central de conflitos, perdendo espaço para outros centros de poder, talvez mais aptos a lidar com a complexidade conflitiva atual, mais adequados em termos de tempo e espaço (Spengler, 2014, p. 26). 
Por outro lado, a relação que une o tempo e a complexidade não depende somente de ambas, mas das suas conexóes, mediante um duplo movimento: aquele da complexidade da temporalizaçáo e aquele simétrico e oposto da temporalização da complexidade. No primeiro se fala de superávit de possibilidades nas conexóes temporais que deixam de ser únicas, direcionadas e monólogas. No segundo, ao contrário, se fala de uma variação da complexidade graças à urgência de conexôes temporais inesperadas (Resta, 2014, p. 32).

Nessa perspectiva, os dois momentos entram em um movimento dialético, pois ambos são rivais e cúmplices ${ }^{1}$, de pontos de vista diversos, ao sugerir, constantemente, as diferenças entre as possibilidades que se encontram confrontadas, a contingência dos eventos e as suas possíveis conexóes. Isso se aplica tanto aos sistemas de personalidade quanto aos sociais, dentre eles a política, o direito, a economia, a ciência, a religiáo, a sociologia.

Apesar desses postulados, tempo, movimento, partes, urgência, entretanto, o Poder Judiciário passa por algumas dificuldades estruturais, como falta de pessoal e estrutura. A conta é paga por toda a população para um serviço que não está acessível a todos os cidadãos e que não cumpre as suas finalidades, sendo extremamente burocrático, lento, formal, procedimental, mecânico e pouco democrático, estando distante da realidade e que, por tal motivo, náo possibilita melhores formas para o tratamento e a resolução dos conflitos. Para Spengler (2014, p. 32), "a crise vem desde os bancos escolares, onde a maior parte das universidades mantém o conservadorismo para o ensino e se acentua na prática com profissionais apegados às formalidades em detrimento da justiça”.

Além disso, cabe elencar os seguintes ensinamentos:

1 Sobre esse fator, cumpre ressaltar um exemplo de Michel Foucault acerca da civilização grega e algumas formas de regulamento judiciário. Referindo-se a Homero, dois guerreiros se afrontavam para saber quem estava errado e quem estava certo, quem havia violado o direito do outro. A tarefa de resolver esta questấo cabia a uma disputa regulamentada, um desafio entre dois guerreiros. Um lançava o desafio. És capaz de jurar diante dos deuses que não fizeste o que eu afirmo. Em um procedimento como este não há juiz, sentença, verdade, inquérito tampouco testemunho para saber quem disse a verdade, quem tem razáo, quanto à luta, ao desafio, ao risco que cada um vai correr (Foucault, 1999, p. 53). 
$\mathrm{Na}$ área jurídica, o pós-graduando é frequentemente um operador do direito, na maioria dos casos integrante do que chamarei, dando a esse conceito um sentido bastante lato, de burocracia judiciária, pois, além de compreender membros do Judiciário sctricto sensu - juízes funcionários de tribunais, etc. -, abrange procuradores, advogados, delegados de polícia. etc. Bem recentemente, fiz um pequeno levantamento junto a meus alunos do ano letivo de 2002. Eram 19 alunos. Desses, nada menos do que 13 - ou seja, $68 \%$ em percentual redondo - integravam o que chamei de burocracia judiciária. Apenas 6 alunos - em percentual, 32\% - compunham o perfil típico de outras áreas: eram apenas bacharéis, alguns com bolsa, e tinham paralelamente a pós-graduação, uma atividade docente. Outros defeitos são apontados, tais como abuso de manuais e de livros de doutrina em detrimento de jurisprudência atualizada e de artigos monográficos, de um lado; a ausência de referência a casos práticos, de outro. Afinal, suprir tais deficiências significaria dedicar-se a atividades de pesquisa que exigiriam do jurista - autor, escrevendo sua tese ou dissertação nos interstícios da elaboração de despachos e pareceres, um esforço bem maior do que o de voltar-se para a estante e pegar os consagrados livros dos doutrinadores que estão à mão! (Oliveira, 2004, p. 145-146).

Esse fator está muito atrelado à cultura normativista técnico-burocrática manifestada de várias formas; dentre outros fatores, a prioridade do direito civil e penal, os dois grandes ramos das faculdades de direito; cultura generalista na qual somente o magistrado tem competência para resolver os litígios, utilizando apenas a lei; desresponsabilização sistêmica que consiste na ideia de que sempre há um problema no sistema, relacionado a outra instância; em um segundo momento, o desempenho distinto com a mesma estrutura burocrática, no mesmo tribunal e, ainda, um baixíssimo nível de ação disciplinar efetiva; o privilégio de poder ligado a privilégios junto da justiça; refúgio burocrático ligado ao andamento dos processos, como, por exemplo, as preferências por decisóes processuais em detrimento de decisóes substanciais (Santos, 2007, p. 67).

Desse modo, acaba se constituindo para a sociedade o distanciamento do direito, pois, embora possa conhecer o direito e a sua relação com os autos, acaba náo tendo conhecimento da relação do processo com a realidade; eis que na cultura dominante impera o dever de aplicar a lei, de forma igualitária a todos os cidadáos; outro fator importante seria o fato de que o direito seria independente das outras 
áreas do conhecimento, isto é, a independência seria uma espécie de autossuficiência (autoindividualismo), não permitindo aprender e, portanto, estabelecer uma relação multidisciplinar com outros ramos do saber, tais como a filosofia, a sociologia, a hermenêutica, a economia, a ciência política e a realidade social daqueles que serão atingidos pela aplicabilidade da norma.

Logo, segundo Spengler (2010, p. 215), “o tempo, assim como perpetua situaçôes de litígios e corrói direitos, tendo o poder de inferir na concepção processual, uma vez que se torna grande controlador da máquina judiciária”. O sistema judicial, neste caso, amparado por um corpo de direitos e procedimentos que garante a previsibilidade na decisão e, concomitante, estabelece como ideal um tratamento igualitário, intermediado por este terceiro neutro, imparcial e distante do próprio conflito, se não é capaz de ser o guardião das expectativas dos que se encontram vulnerabilizados pelas condiçóes econômicas e sociais, ao menos permite que o conflito não seja abandonado a um campo de forças que, de saída, é plenamente desfavorável aos carentes de informação, status ou poder econômico (Rebouças, 2012, p. 181-182). Destacamos as respectivas liçóes:

\begin{abstract}
Nos marcos da crise de valores e do desajuste institucional no âmbito de sociedades periféricas de massa, como a nossa a brasileira, da estruturação das novas formas racionais de legitimação da produção capitalista, de saturamento do modelo da representação política e do esgotamento instrumental jurídico estatal, perpassa pela necessidade de empreender o esforço para que seja viável alcançar um novo paradigma de fundamentação para a cultura política e, também, a cultura jurídica. A construção de uma nova instância de normatividade social será capaz de abrir um horizonte que, de fato, transcenda às formas de dominação da modernidade burguês - capitalista e de sua racionalidade formal opressora do mundo da vida (Wolkmer, 1997, p. 155).
\end{abstract}

As imbricações entre tutela jurisdicional e tempo são visíveis, especialmente quando há uma resposta estatal às expectativas sociais e normativas, bem como uma forma importante de proteção do indivíduo à lesão ou ameaça de lesão mediante o direito de ação. Essas imbricaçôes, entretanto, tornam-se débeis quando se verifica que a tutela jurisdicional acontece a destempo. A distribuição desigual das chances de vida é um resultado das estruturas de poder. É o que se pode verificar nos textos 
de Marx, ao centrar a discussão no fato de que os indivíduos possuem uma essência nata e interesses predeterminados, porém não agem conforme tais interesses porque são enganados pelo sistema social (Spengler, 2010, p. 269).

Logo, esses conjuntos de relaçôes sociais vão se constituindo e necessitam ganhar contornos jurídicos em razão da economia mercantil. $O$ direito passa a ser utilizado como mecanismo da estrutura econômica capitalista para a dominaçáo do trabalhador pelo burguês; a regulamentação da propriedade, os lucros, os contratos de trabalho, a liberdade individual, a igualdade de oportunidades, a compra e venda, tudo que possibilite o lucro para os dominadores, têm no Estado o garantidor do capital, da ordem e de suas relaçóes sociais e, por consequência, jurídicas (Mascaro, 2008, p. 108).

Assim, a teoria marxista afirma que a sociedade consiste em um equilíbrio instável de forças contrapostas, as quais, por meio de suas lutas e tensóes, geram transformaçáo social, apontando ainda o conflito social como elemento determinante do processo histórico e descrevendo o Estado como um instrumento de domínio de classes, de domínio político e um reflexo e expressão do conflito entre essas classes. Observa, também, que o Estado sustenta as condiçóes sociais que asseguram a permanência de um grupo dominante no poder em defesa dos próprios interesses.

Por outro lado, não podemos olvidar que o paradigma jurídico dogmático (ensino), a cultura técnico-burocrática, a expansão das faculdades de direito, a educação bancária, a extensão nos cursos de direito, a formação dos professores (preparação pedagógica), a dogmática jurídica (direito oficial), também incluem fatores preponderantes na formação do jurista. A educação jurídica deve ser intercultural, interdisciplinar e profundamente imbuída de responsabilidade cidadã, como forma de revolucionar democraticamente a justiça. Somente assim seria possível vencer os três pilares da cultura normativista técnico burocrática (autonomia do direito, excepcionalismo do direito e concepção burocrático-técnica dos processos) (Santos, 2007, p. 73).

A crise do Estado e do Poder Judiciário, portanto, é inegável. Essa crise tende a ganhar proporçôes de maior envergadura, uma vez que não sejam adotadas novas formas para o tratamento de conflitos, haja vista a falta de eficiência do Estado na contrapartida necessária à população em suas demandas judiciais e, especialmente, 
na forma como deve ser tratado o conflito. O Estado, enquanto intermediário das relações sociais, no exercício de sua função de mediador, em razão dos fundamentos expostos, encontra-se embaraçado em uma insolúvel contradição interna, dividido em antagonismos inconciliáveis, sucumbindo aos interesses das classes dominantes e econômicas, ligados a uma cultura jurídica sistemática (fechada em si mesma), individualista, burocrática, normativista, individual e processualista.

No próximo ponto será abordado o instituto da arbitragem como novo paradigma para a resolução de conflitos no âmbito da administração pública, a partir de algumas modificaçóes propostas pelo Senado Federal que alteram alguns dispositivos da Lei 9.307/96 (Lei de Arbitragem).

\section{A LEI DA ARBITRAGEM NO ÂMBITO DA ADMINISTRAÇÃO PÚBLICA}

No Brasil, este instituto é legalmente conhecido desde os tempos da colonização portuguesa e, atualmente, vem encontrando um novo caminho, como provam a criação de várias câmaras arbitrais e a elaboração de projetos de lei, das quais o último, de autoria do senador Marco Maciel, culminou na Lei 9.307/96. O Código Comercial Brasileiro de 1850 estabeleceu o arbitramento obrigatório para as causas entre sócios de sociedades comerciais (Morais; Spengler, 2012, p. 214).

Em 1990, pela primeira vez, o STJ reconheceu a eficácia da cláusula compromissória em contrato internacional, dispensando o compromisso arbitral posterior. Foi com a promulgação da Convenção do Panamá de 1975 (que valida a cláusula arbitral em contratos internacionais), em maio de 1996, que se sedimentou uma nova mentalidade acerca da arbitragem no Brasil. A partir de então não se faz mais distinção entre arbitragem interna e internacional (Morais; Spengler, 2012, p. 215).

Esta lei substituiu o modelo de juízo arbitral, disciplinando a convenção de arbitragem, prestigiando a manifestação da vontade, inclusive versando sobre a ética dos árbitros. Ainda existem outros fatores gerais que inspiraram o despertar do interesse no referido instituto, tais como: a) vícios da via judiciária; b) crescente complexidade dos negócios; c) natureza do procedimento arbitral; d) certeza da aplicação da norma desejada; e e) crescente facilidade da execução das sentenças arbitrais. 
A entrada em vigor da Lei 9.307/96 representou uma transformação que adveio, em grande parte, da importância desta fórmula como instituto jurídico ante a relaçóes comerciais internacionais, avolumadas e intricadas por transformaçóes econômicas no cenário mundial, particularmente a transnacionalização da economia e a construção de blocos supranacionais. A lei em questão buscou revigorar o juízo arbitral. Sendo assim,

A arbitragem aparece como uma estratégia de extrema importância, pois, como se verá, o Estado confere à mesma algumas faculdades jurisdicionais, como outorgar às decisōes arbitrais força de coisa julgada, sem a necessidade de homologação das mesmas pelos tribunais estatais. As partes, ao fazerem a opção pela justiça arbitral, afastam a jurisdição estatal substituindo-a por outra estratégia de tratamento de conflitos, reconhecida e regulada pelo Estado de modo que permite a execuçáo das decisões ali proferidas bem como a anular das decisōes que não observem o mínimo de regras exigidas pelo legislador. Na Lei 9.307/96, encontramos a possibilidade de remissão de questóes à autoridade judiciária competente, desde que envolvam direitos indisponíveis e sejam fundamentais ao julgamento arbitral (artigo 25) (Morais; Spengler, 2012, p. 222).

Destacam-se algumas características presentes na arbitragem: amplia a liberdade de contratação; pode ser usada em qualquer controvérsia que envolva direito patrimonial disponível; justiça de técnicos; e permite ao árbitro disciplinar o procedimento caso não haja convenção das partes neste sentido é acrescido, ainda, o fato de possibilitar maior celeridade no tratamento de conflitos, inclusive com estabelecimento de prazo para sentença arbitral, bem como a possibilidade de sigilo do procedimento arbitral e, igualmente, transformando a sentença arbitral em título executivo judicial.

Algumas características demonstram a peculiaridade da arbitragem, especialmente se analisado acerca de suas categorias: arbitragem de direito público (ocorre entre Estados) e de direito privado; entre particulares, ainda sob a possibilidade de ocorrer uma arbitragem mista envolvendo Estado e particular; arbitragem ad hoc, em que as partes definem o desenvolvimento da arbitragem e, caracterizada pela informalidade e institucionalizada, pressupóe a existência de uma institucionalização especializada, com regulamento próprio e lista de árbitros. 
É necessário assinalar ainda a diferença entre a arbitragem equitativa (na qual os árbitros ficam livres para decidir o litígio segundo seu senso comum, formulando e aplicando uma regra de acordo com o caso em análise) e a arbitragem de direito (quando os árbitros decidirão com base em princípios estritamente jurídicos, de acordo com o direito positivo). O tema da natureza jurídica é justamente o ponto de maior polêmica entre os doutrinadores - situar a arbitragem no campo do direito. Assim, questiona-se: A arbitragem pertence ao direito público ou privado? (Morais; Spengler, 2012, p. 228).

Segundo a Tese Contratualista: a arbitragem possui um caráter privatista tanto no que se refere a sua origem quanto a respeito da qualidade dos árbitros. Baseia-se no fato de que no que diz respeito a direitos disponíveis não pode o Estado privá-las da faculdade de escolher o método para resolvê-las. Nesta Tese inexistirá arbitragem sem convenção de arbitragem; o caráter puramente fundante da arbitragem é o consenso entre as partes enquanto a jurisdição assenta na soberania do Estado; o árbitro não compóe a estrutura judiciária e o laudo arbitral não tem sua coercibilidade assegurada. Já segundo a Tese Jurisdicional: fundamenta-se no caráter público da administração da justiça, figurando seu laudo como uma sentença proferida por um magistrado em sua função jurisdicional do Estado (Morais; Spengler, 2012, p. 229).

A lei prevê, em seu artigo 13, que qualquer pessoa capaz, que tenha confiança das partes, poderá ser árbitro, não descrevendo a obrigatoriedade acerca de a função ser desempenhada por pessoas naturais, porém esta vem sendo a interpretação do dispositivo. A lei prevê, ainda, em seu $\$ 6^{\circ}$ do mesmo dispositivo supramencionado, que a atuação do árbitro deverá se pautar pela imparcialidade, independência, competência, diligência e discrição. No artigo 17 equipara o árbitro ao funcionário público, e no artigo 18, do mesmo diploma legal, define que o árbitro é juiz de fato e de direito, fazendo dele um juiz privado, distinguindo do arbitrado que apenas examina os fatos.

O fato de os árbitros administrarem a justiça por vontade das partes não é razão para negar caráter público a sua atividade, pois, em última instância, estão fazendo por conta do Estado que tem interesse em que as disputas sejam resolvidas de maneira pacífica. A base contratual da arbitragem é o compromisso, de caráter 
estritamente consensual, e que estabelece as diretrizes de juízo arbitral que institui. Não é porque o juízo arbitral tem simplificação do procedimento que irá ignorar princípios, como o devido processo legal e o contraditório.

Náo se pode confundir compromisso com cláusula compromissória, embora ambos têm por fim a renúncia à jurisdição ordinária. O primeiro refere-se a uma questáo já existente, enquanto a cláusula visa a questôes futuras. Independentemente das regras estabelecidas para o procedimento arbitral, estas devem obedecer alguns princípios: princípio do contraditório; princípio da ampla defesa; princípio da igualdade de tratamento; princípio da imparcialidade e da independência; princípio da disponibilidade; e princípio do livre-convencimento do julgador (Morais; Spengler, 2012, p. 234-235).

Uma das grandes inovaçôes da lei é que qualquer recusa, nesse sentido (da declaração de vontade), gera para a outra parte o direito de obter em juízo a tutela jurisdicional específica daquela obrigaçáo. Segundo a lei, independente da existência de cláusula sobre os termos do compromisso, poderá a parte exigir, em juízo, seu cumprimento forçado, inclusive nomeando árbitro ou instituição arbitral, valendo a sentença como compromisso arbitral (artigo 10). Além de satisfazer as exigências formais da Lei $9.307 / 96$ (artigo $4^{\circ}, \$ 2^{\circ}$ ), sua eficácia ainda pode ser discutida a partir das regras de defesa do consumidor. Isto porque, por força dos artigos $6^{\circ}$ e $7^{\circ}$ da mesma lei, a cláusula compromissória prescinde de ato subsequente do compromisso arbitral.

A cláusula arbitral pode sofrer alguns problemas com relação a sua validade: no que se refere à violaçáo de dispositivo legal do Estado que rege arbitragem ou ausência de poder de autoridade contratante e na separaçáo da cláusula arbitral. Sáo peculiaridades desta norma conter cláusulas obrigatórias e facultativas (artigos 10 e 11), além de poder assumir forma judicial ou extrajudicial. Qualquer que seja a convenção de arbitragem ela configura um impedimento processual, e, para tal, deve atender alguns requisitos: forma escrita, capacidade e consentimento das partes e objeto lícito - arbitrabilidade (Morais; Spengler, 2012, p. 238- 239).

A sentença arbitral não é igual à sentença judicial, mas produz os mesmos efeitos da sentença prolatada por órgão dos Poder Judiciário. A decisão arbitral não depende de homologação do Judiciário para adquirir força executiva. A Lei 
introduziu uma nova natureza para a decisão arbitral. São requisitos que devem estar presentes no laudo arbitral: prazo de entrega, a decisão reduzida a termo e os mesmos elementos da sentença judicial. A não apresentação de todos os requisitos poderá gerar a anulação do laudo por meio de ação de anulação movida no Judiciário (Morais; Spengler, 2012, p. 244-245).

Tramita no Senado Federal o Projeto de Lei que tem por iniciativa que os artigos $1^{\circ}, 2^{\circ}, 4^{\circ}, 13,19,23,30,32,33,35$ e 39 da Lei no 9.307 , de 23 de setembro de 1996, estabeleçam uma série de acréscimos à Lei de Arbitragem, ampliando o rol de aplicação do instituto, especialmente no âmbito da Administração Pública.

Preceitua o artigo $1^{\circ}$, parágrafo $1^{\circ}$, que a Administração Pública direta e indireta poderá utilizar-se da arbitragem para dirimir conflitos relativos a direitos patrimoniais disponíveis decorrentes de contratos por ela celebrados. Nessa hipótese, estamos diante das espécies contratuais estabelecidas pela Administração Pública. Os contratos referidos pelo projeto de Lei, dizem respeito aos contratos previstos no artigo 24, caput e seguintes da Lei de Licitações (Lei. 8.666/93). Ainda, a Constituição Federal, estabelece em seu artigo 175, que incumbe ao Poder Público, na forma da lei, diretamente ou sob o regime de concessão, cessão ou permissão, sempre mediante licitação, a prestação de serviços públicos.

Cerca de 16 vereadores, ex-vereadores, servidores públicos e empresários no Rio Grande do Norte, Natal, foram condenados, em janeiro/2012, por comercializarem o Plano Diretor da capital potiguar, em 2007, pelo valor aproximado, para cada um, de R \$30.000,00, não tendo passado um dia atrás das grades, aguardando julgamento dos recursos interpostos (Leal, 2013, p. 152). Nesse caso, envolvendo interesse patrimonial da Administração Pública, as partes poderiam escolher árbitros para julgamento? Ainda, em caso de superfaturamento de uma obra, envolvendo direito patrimonial e, consequentemente, o estabelecimento de relação contratual, poderiam as partes eleger árbitro para solverem a questão?

Em relação ao artigo $2^{\circ}, \$ 3^{\circ}$, do projeto de Lei, estabelece que a arbitragem pode ser de direito ou de equidade, a critério das partes. Quando envolver a Administração Pública será sempre de direito e respeitará o princípio da publicidade. Nesse dispositivo, verifica-se que não apenas a publicidade, mas os demais princípios que regem a Administração Pública, dentre eles a legalidade, a impessoalidade, a 
moralidade e a eficiência deveriam estar inclusos no texto do projeto, em atendimento aos princípios elencados no artigo 37 da Constituição Federal. Sendo assim, cabe destacar que:

No âmbito das atividades constituintes, destaca-se a ideia de democratização do Estado - com o fortalecimento do controle externo da administraçáo pública, especialmente com o papel do Ministério Público e da sociedade civil. É na constituição de 1988, que os princípios regentes da administração pública brasileira são encontrados, especialmente no que diz respeito à legalidade, à publicidade e à moralidade administrativa (Artigo 37). Além disso, é importante salientar o papel da descentralização estipulado pela Constituição, bem como o compromisso estabelecido de reforma do serviço civil, por meio do reconhecimento e da universalização da meritocracia e participação da cidadania (Filgueiras, 2011, p. 135-136).

Aqui, nesse ponto, temos um conflito entre a arbitragem e os princípios que regem a Administração Pública. Se o procedimento arbitral requer a possibilidade do sigilo e a escolha do arbitro, como ficaria em caso de conflitos com os princípios da publicidade e imparcialidade previstos na Constituiçáo? O novo projeto de Lei do Senado, nesse aspecto, é omisso, não fazendo qualquer menção a essa possibilidade quanto ao choque principiológico; mais, ainda, em caso de solução entre as partes e havendo a supremacia do interesse público.

O novo texto legal, em seu artigo $4^{\circ}$, define a cláusula compromissória como sendo a convenção pela qual as partes, em um contrato, comprometem-se a submeter à arbitragem os litígios que possam vir a surgir relativamente a tal contrato. Acrescenta como nova hipótese à Lei da Arbitragem o parágrafo $4^{\circ}$, do referido dispositivo, prevendo que o empregado que ocupe ou venha a ocupar cargo ou função de administrador ou diretor estatutário, nos contratos individuais de trabalho poderá ser pactuada cláusula compromissória, que somente terá eficácia se o empregado tomar a iniciativa de instituir a arbitragem ou se concordar, expressamente, com a jurisdição.

Duas questôes merecem destaque em relação ao dispositivo: primeiro, conforme a leitura, os servidores vinculados a algum órgáo da administração pública direta ou indireta, que ocupem cargo ou função de administrador ou diretor 
estatutário, isto é, um servidor de carreira ou cargo de confiança, no âmbito de uma Empresa Pública Federal, poderá, em contrato individual de trabalho, ou seja, intuito persona, instituir a arbitragem, ou, ainda, deverá expressar anuência expressa com sua jurisdição. Vale ressaltar que a legislação é clara ao prever, de forma única, a hipótese acerca do contrato individual.

Outro fator importante seria em relação à iniciativa ou concordância do empregado, de forma expressa, em aceitar a jurisdição de arbitragem. Apesar da possibilidade da instituição da jurisdição arbitral e da autonomia da vontade das partes em requerer a eleição de um arbitro para tratamento do seu respectivo conflito, a flexibilidade em relação à instituição ou concordância tendem ao enfraquecimento do instituto, posto que deve haver a iniciativa por parte de quem está figurando no polo ativo; de igual modo, concomitantemente, exige a anuência da parte que figura no polo passivo, bastando à parte contrária náo aceitar a submissão à jurisdiçáo, ou sequer comparecer à audiência, em razão da faculdade que lhe é permitida.

No artigo $13^{\circ}, \$ 4^{\circ}$, observa-se que a Lei permite que as partes, de comum acordo, poderão afastar a aplicação de dispositivo do regulamento do órgão arbitral institucional ou entidade especializada, que limite a escolha do árbitro único, coárbitro ou presidente do tribunal à respectiva lista de árbitros, autorizado o controle da escolha pelos órgãos competentes da instituição. Nos casos de impasse e arbitragem multiparte, deverá ser observado o que dispuser o regulamento aplicável.

É consenso o reconhecimento da arbitragem como um dos rituais de resolução de conflitos mais antigos registrados. Ao mesmo tempo, parece não haver outro argumento tão forte que justifique seu apagamento ao longo dos últimos séculos que não aquele que indica a centralização hegemônica nas mãos do Estado dos meios de resolução de conflitos. O império da lei afastou o juízo de equidade, típico da arbitragem, do ideal de segurança jurídica, apoiando-se, quase que exclusivamente, na construção de um ordenamento autossuficiente.

Nesta oportunidade, o próprio Estado, em um movimento de fortalecimento, chamou para si a função jurisdicional e se fez exclusivo nesta empreitada diante do monopólico da sanção e do direito. Nas liçóes de Rebouças (2012, p. 171), "a medida da liberdade permitida pelo Estado é justamente aquela que nos faz sujeitos de direito, submetidos à suas normas”. 
A arbitragem pressupóe, igualmente, uma concepção mais forte de contrato, posto que na autonomia e reflexão das partes esteja incluído o consenso sobre a forma futura de resolução de conflitos porventura advindos daquela relação. Há quem veja, no entanto, não exatamente um acento na possibilidade contratual, que equivaleria a reduzir a arbitragem a uma vontade, mas sim um acento na característica negocial da arbitragem como negócio jurídico.

A arbitragem concentra, assim, se comparada com o sistema judicial, ainda mais autoridade nas mãos de seu decididor. Restringe o debate, retira das partes a possibilidade de decisão e de pensar o conflito, e concentra-se no resultado. As partes envolvidas participam ativamente da própria escolha do sistema, focando entre os limites contratuais da disputa e a credibilidade e adequaçáo do árbitro. Escolhido o árbitro ou o Tribunal arbitral, cessam as falas e somente se concede voz ao próprio árbitro. Em um monólogo, ele profere sua sentença e põe termo ao conflito (Rebouças, 2012, p. 176).

Ao esvaziar o grau de qualidade da legalidade, em uma perspectiva voltada para as demandas empresariais, os árbitros atendem aos referenciais de caráter privado, celeridade, confidencialidade, decisão por equidade, tratamento equânime, conflito resolvido por meio de técnico referente ás suas demandas e alheios às preocupaçóes de caráter público e social; o segredo arbitral e o afastamento dos imperativos legais que regem a Administração Pública, pela análise do novo projeto da Lei de Arbitragem, opera na lógica da reprodução econômica contemporânea, atendendo aos anseios do sistema capitalista de produção chancelando a legalidade direita e indiretamente voltada para os seus interesses.

\section{CONSIDERAÇÕES FINAIS}

Está muito presente no senso comum teórico dos juristas o conflito, remetendo à ideia de litigiosidade no tratamento às demandas individuais e sociais, bem como à ideia de conflito/litígio. Desse modo, a resposta mais eficiente, satisfatória e célere por parte do Estado e do Direito, nas tomadas de decisão, seria o uso alternativo de soluções para as demandas judiciais. $\mathrm{Na}$ forma como vem sendo realizado o tratamento acerca dos conflitos sociais, pode-se correr o risco do uso 
da violência não física, e, realizado por intermédio da lei, enquanto via indireta na relação justiça e cidadão, em uma perspectiva marxista, é entendido como aparelho repressivo e ideológico de Estado, por atender aos interesses das classes dominantes e do sistema capitalista de produção.

De outro modo, a crise do Estado e do Poder Judiciário é inegável, podendo ganhar maior proporção e envergadura, caso o sistema judicial continue sendo uma montanha composta de uma série escalada, priorizando o direito material/substancial em razão dos procedimentos, isto é, do processo formal de decisão judicial, sem a busca ideal acerca de um tratamento igualitário na relação mediadora entre as partes e o árbitro.

O novo projeto de Lei que objetiva instituir a previsão normativa do instituto da Arbitragem, no que respeita à matéria envolvendo interesse patrimonial da Administração Pública, todavia, exige uma cautela do legislador constituinte ordinário, pois, em se tratando de interesse público e dos princípios administrativos constitucionais, não se mostra crível pressupor uma concepção no estabelecimento de uma relação contratual e arbitral, posto que na autonomia da vontade e reflexão das partes é incluído o consenso sobre a forma futura de resolução de conflitos porventura advindos daquela relação, em havendo o interesse da coletividade a ser objeto de proteção jurídica.

\section{REFERÊNCIAS}

ALTHUSSER, Louis. Aparelhos Ideológicos do Estado. Rio de Janeiro: Ediçóes Graal, 1985,

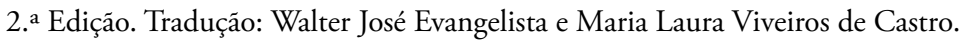

FILGUEIRAS, Fernando. Corrup̧̧âo e sistema político no Brasil. Rio de Janeiro: Civilizaçáa Brasileira, 2011.

FOUCAULT, Michel. A verdade e as formas jurídicas. Tradução Roberto Cabral de Melo Machado e Eduardo Jardim Morais. Rio de Janeiro: Nau Ed., 1999.

LEAL, Rogério Gesta. Patologias corruptivas nas relaçōes entre Estado, administração pública e sociedade. Causas, consequências e tratamentos. Santa Cruz do Sul: Edunisc, 2013.

MASCARO, Alysson Leandro. Crítica da legalidade e do Direito brasileiro. São Paulo: Quartier Latin, 2003. 
Liçôes de Sociologia do Direito. São Paulo: Quartier Latin, 2008.

MORAIS, Jose Luís Bolzan de; SPENGLER, Fabiana Marion. Mediação e arbitragem: alternativas à jurisdição. Porto Alegre: Livraria do Advogado, 2012.

MULLER, Jean-Marie. Oprincípio da não-violência: uma trajetória filosófica. Tradução Inês Polegato. São Paulo: Palas Athena, 2007.

OLIVEIRA, Luciano. Sua excelência o comissário e outros ensaios de sociologia jurídica. Rio de Janeiro: Editora Letra Legal, 2004.

RESTA, Eligio. Tempo e processo. Santa Cruz do Sul: Essere Nel Mondo, 2014.

REBOUÇAS, Gabriela Maia. Tramas entre subjetividades e direito: a constituição do sujeito em Michel Foucault e os sistemas de resolução de conflitos. Rio de Janeiro: Lumen Juris, 2012. SANTOS, Boaventura de Souza. Para uma revolução democrática da justiça. São Paulo: Editora Cortez, 2007.

SPENGLER, Fabiana Marion. Da jurisdição à mediação. Por uma nova cultura no tratamento de conflitos. Ijuí: Ed. Unijuí, 2010.

. Fundamentos políticos da mediação comunitária. Ijuí: Ed. Unijuí, 2012. . Retalhos de mediação. Santa Cruz do Sul: Essere Nel Mondo, 2014.

WOLKMER, Antônio Carlos. Pluralismo jurídico: fundamentos para uma nova cultura no Direito. São Paulo: Editora Alfa Ômega, 1997.

Recebido em: 16/2/2016

Aceito em: 6/5/2016 